\title{
"Stochastic frontiers of efficiency for Brazilian investment funds: a panel data analysis"
}

Luis Ferruz Agudo (D https://orcid.org/0000-0002-3816-9747

João Serafim Tusi da Silveira (D) https://orcid.org/0000-0002-0720-5020

AUTHORS

Daniel Knebel Baggio (D https://orcid.org/0000-0002-6167-2682

Isoé Nícolas Schneider (D) https://orcid.org/0000-0002-2806-5135

Maria Margarete Baccin Brizolla (D https://orcid.org/0000-0002-5120-0729

Luis Ferruz Agudo, João Serafim Tusi da Silveira, Daniel Knebel Baggio, Isoé Nícolas Schneider and Maria Margarete Baccin Brizolla (2019). Stochastic

ARTICLE INFO frontiers of efficiency for Brazilian investment funds: a panel data analysis. Investment Management and Financial Innovations, 16(4), 352-365. doi:10.21511/imfi.16(4).2019.30

DOI http://dx.doi.org/10.21511/imfi.16(4).2019.30

RELEASED ON

Thursday, 26 December 2019

RECEIVED ON

Monday, 23 September 2019

ACCEPTED ON

Tuesday, 10 December 2019

\section{(c) E EY}

LICENSE

This work is licensed under a Creative Commons Attribution 4.0 International License

JOURNAL

"Investment Management and Financial Innovations"

ISSN PRINT $1810-4967$

ISSN ONLINE $1812-9358$

PUBLISHER

LLC "Consulting Publishing Company "Business Perspectives"

FOUNDER

LLC "Consulting Publishing Company "Business Perspectives"

NUMBER OF REFERENCES

52
NUMBER OF FIGURES

0
NUMBER OF TABLES

4

(C) The author(s) 2022. This publication is an open access article. 


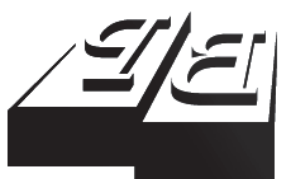

BUSINESS PERSPECTIVES

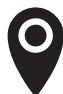

LLC "CPC "Business Perspectives" Hryhorii Skovoroda lane, 10, Sumy, 40022, Ukraine

www.businessperspectives.org

Received on: $23^{\text {rd }}$ of September, 2019 Accepted on: 10 ${ }^{\text {th }}$ of December, 2019

(C) Luis Ferruz Agudo, João Serafim Tusi da Silveira, Daniel Knebel Baggio, Isoé Nícolas Schneider, Maria Margarete Baccin Brizolla, 2019

Luis Ferruz Agudo, Doctor in Accounting and Finance, Department of Accounting and Finance, University of Zaragoza, Spain.

João Serafim Tusi da Silveira, Doctor in Production Engineering, Professor Federal University of Santa Catarina, Brazil.

Daniel Knebel Baggio, Doctor in Accounting and Finance, Professor, Universidade Regional Integrada e das Missões e Universidade Regional do Noroeste do Estado do Rio Grande do Sul - UNIJUI, Brazil.

Isoé Nícolas Schneider, Master in Regional Development, DACEC, Universidade Regional do Noroeste do Estado do Rio Grande do Sul UNIJUÍ, Brazil.

Maria Margarete Baccin Brizolla, Doctor in Accounting and Administration, Professor, Universidade Regional do Noroeste do Estado do Rio Grande do Sul UNIJUI, Brazil.

\section{(ㄷ) (i)}

This is an Open Access article, distributed under the terms of the Creative Commons Attribution 4.0 International license, which permits unrestricted re-use, distribution, and reproduction in any medium, provided the original work is properly cited.
Luis Ferruz Agudo (Spain), João Serafim Tusi da Silveira (Brazil),

Daniel Knebel Baggio (Brazil), Isoé Nícolas Schneider (Brazil),

Maria Margarete Baccin Brizolla (Brazil)

\section{STOCHASTIC FRONTIERS OF EFFICIENCY FOR BRAZILIAN INVESTMENT FUNDS: A PANEL DATA ANALYSIS}

\begin{abstract}
Foundations, methodological and empirical possibilities of measurement and analysis in the performance of financial investments within investment funds have been developed since they were once introduced in the 1970s, thus establishing a path of growing acceptance in financial markets and universities' academies. The first approaches over the efficiency of these funds, considering their stochastic implications, occurred in the late 1990s and have evolved with the help of SFA - Stochastic Frontier Analysis, although it still needs more careful verification. This article measured and analyzed the stochastic frontier of efficiency over 33 different Brazilian investment funds from 2012 to 2015. For doing so, Battese and Coelli's (1995) specifications was used. It shows the effects of inefficiencies, which are defined as explicit functions of specific factors in the context of panel data funds. They are estimated by the maximum likelihood method. Sharpe ratios (SR) were also calculated for comparative purposes. Based on these two indicators (SFA and SR), the most recommendable funds to invest and the ones in which the application should not be performed were identified. Such procedures have stimulated the necessary and promising studies, as well as future researches, which, in turn, may establish new methodological formulation as an efficient and effective instrument to choose the best and the safest funds to invest.
\end{abstract}

Keywords efficiency, performance, investment funds

\section{JEL Classification G23, G24}

\section{INTRODUCTION}

Investment funds are one of the most important investment options in today's financial market, due to their increasing quantity and to the options available, and for the importance they have in domestic savings and in the allocation of resources in productive activities (Amaral, Vilaça, Barbosa, \& Bressan, 2004). They are the determinants for the economic development of regions, where resources are applied (Baggio, 2012).

According to Fundação Getúlio Vargas [FGV] (2017), Brazilian funds market is the tenth largest in the world, with approximately $3 \%$ out of the total world equity. Currently, more than 15,000 funds are under management in Brazil, and are also notable for the variety of products offered and the diversity of investors (Brazilian Association of Financial and Capital Market Entities [ANBIMA], 2017).

The underlying idea of efficiency ratios is that individuals act as risk enemies who expect greater profitability for taking greater risks. The measures of efficiency, when relating average profitability with risk, indicate how the portfolio is rewarding in terms of profitability, the assumed risk. 
The literature is rich on performance evaluation of investment funds. Recently, some authors have used different methodologies to contrast the efficiency's performance of investments based on Data Envelopment Analysis (DEA) and/or Stochastic Frontier Analysis (SFA) (Galan, Ramos, \& Veiga, 2015; Mamatzkis \& Xu, 2016), among others.

These two methodological approaches configure the determination of efficiency's frontiers. The DEA methodology is non-parametric, deterministic, and efficiency's frontier is determined by mathematical programming. SFA methodology is parametric, non-deterministic, and stochastic efficiency frontier is determined econometrically. Data Envelopment Analysis considers the manager's inefficiency as all the inefficiencies registered by the fund, or how close it was to be totally efficient. On the other hand, in Stochastic Frontier Analysis, the inefficiency of the manager is deducted from the total inefficiency of the fund, subtracting from it the part beyond its control.

In this regard, we sought to contribute to a deeper knowledge in the analysis of the efficiency of Brazilian investments funds, by identifying the variables which impact either positively or negatively the funds' efficiency. The use of Stochastic Frontier Analysis turned it all possible, despite its infrequent use in the investment analysis of Brazilian investment funds. In this regard, we sought to contribute to a deeper knowledge in the analysis of the efficiency of Brazilian investments funds, by identifying the variables which impact either positively or negatively the funds' efficiency. The use of Stochastic Frontier Analysis turned it all possible, despite its infrequent use in the investment analysis of Brazilian investment funds. From important and significant variables identified in the efficiency model, performance rankings of investment funds were established in order to help investors in their decision-making. Yet, to help fund managers who may compare their financial products performance with the ones from other institutions. Therefore, this study can be recognized as original by the econometric method used to measure the funds efficiency, and for the variables found and the effects they have on efficiency.

Next to the introduction, a review on the literature over performance measurements and investment funds efficiency is presented. After that, the aim of the article, and then the models of stochastic frontiers and the econometric model specifications are detailed. Section 4 presents the results and the debate. Finally, the conclusion and the bibliographic references are presented.

\section{LITERATURE REVIEW}

Many performance measures have been used since the pioneering theory of portfolios, which was developed by Markowitz (1952). In the understanding of Vargas (2006), Baggio, Silveira, Schneider, Maciel and Oliva (2018) and since it is based on a portfolio theory, the Sharpe Index (1964) should be used to evaluate the performance of diverse portfolios, once it measures the risk through standard deviation. When this ratio is applied to a poor diversified portfolio, it is often undervalued for the excessive risk, which could be reduced by a proper diversification.

Thus, it would not be entirely correct to apply the Sharpe Index to specialized portfolios, which by definition do not embrace any diversification. For such cases, the Capital Asset Pricing Model
(CAPM) is recommended, once it advocates the securities and portfolios should yield according to their systematic risk, measured by beta. This process leads to ratios such as the ones used by Treynor (1965) and Jensen (1968).

Jensen (1968) was a pioneer in the analysis of predictive capacity of investment fund managers. This author evaluated the capacity of 115 US mutual funds from 1945 to 1964 using a model derived from Sharpe (1964), the Capital Asset Pricing Model (CAPM). He concluded that there is little evidence that any individual fund can perform better than expected.

Over time, new and more sophisticated forms of performance measurement have been developed, such as market timing and conditional performance measures, which are not based on histori- 
cal returns. They consider the state of the economy every time there is profit and the ability of managers to provide the extraordinary returns.

Treynor and Mazuy (1966) have analyzed the annual return of 57 US funds and assumed that in only one of the funds, the hypothesis of market timing was not rejected. Merton (1981), on the other hand, has formalized the analysis of value creation by market timing, in which the manager predicts the highest market return in relation to the risk-free asset, and vice versa, but cannot predict its magnitude.

Henrikson and Merton (1981) have performed both tests, parametric and non-parametric, in order to measure the funds' performance according to market timing. It did not require though, restrictive market assumptions in equilibrium and it followed rationality and efficiency tests considered by Fama (1970). Henrikson (1984) applied these tests in the American market from 1968 to 1980 in 116 funds, and he has found only three funds with a positive market timing ability, so, proving their non-existence.

Grinblatt and Titman (1989) compared the abnormal returns of passive and active investment funds during the period from 1975 to 1984 , and they got the conclusion that some of the highest performance can be considered the result of active management of the funds. Carhart (1997) analyzed the fund performance investment during the period from 1962 to 1993 . The result has confirmed the hypothesis of lack of skill on the part of the managers. Adding to it, the moment factor of Jegadeesh and Titman (1993), which corresponds to the difference between shortterm gaining returns and losing portfolios, to the three-factor model of Fama and French (1993), Mayorga and Marcos (1996) introduced in their analysis the incidence of rates and costs passed on to investment funds management, without obtaining the results significantly different from those obtained in previous studies.

Franz and Figueiredo (2003) found no evidence of market timing ability in 29 Brazilian mutual stock funds from 1995 to 2000. Barbosa and Sarto (2007) studied a sample of nine ANBID categories (currently ANBIMA) of Brazilian investment funds, based on the performance measures of Treynor (1965), Sharpe (1966), and Jensen (1968), verifying that the management classification is accompanied by strong similarities, according to different measures.

Malacrida, Yamamoto, Lima, and Pimentel (2007) compared the performance of Brazil's variable income funds with Ibovespa's benchmark and assumed that many managers cannot overcome the benchmark over the years. This article presents the results of a study, which was carried out by Casaccia (2009), Baggio, Silveira, Schneider, Maciel, and Oliva (2018), examining the Brazilian variable income funds from different performance measures. The conclusion is there are no substantial distinctions among the applied performance measures.

Leusin and Brito (2008), in turn, found the evidence of market timing ability in a minority of fund managers from 1998 to 2003, apparently due to greater predictability of large differences in the returns between the stock market and the risk-free interest rate.

Fama and French (2010) analyzed the American funds from 1984 to 2006 in order to show whether the performance occurs by skill, or merely luck. The results showed that the net return obtained by the investors was lower than CAPM benchmarks and than three and four factor models, concluding that few funds can cover their costs.

Baggio, Ferruz, and Marco (2010) analyzed the relationship between the performance and the increase in the equity of Brazilian variable income investment funds, considering 459 funds from January 1997 to December 2006. Comparing the averages of the annual, semi-annual, and quarterly results, the persistence of the performance and the relation between it and future movements of capital was shown, especially in the short periods. From 1998 to 2009, Matos and Nave (2012) detected a level of unusual persistence in the stock funds due to the manager's expertise.

In the research of 75 different Ibovespa assets funds from January 1998 to December 2008, 
Silva (2012) identified those which were the result of simply luck and those obtained through the ability of their managers, using the methodology proposed by Fama and French (1993). For the analysis of fund performance, Silva (2012) used the methodology proposed by Fama and French (2010) and verified that most of the funds that outperformed had this kind of performance due to chance, while three of them showed a truly superior performance due to their manager's skills.

According to the studies and the research summarized so far, it can be noticed the great attention given to indicate the best investment to make since the creation of classic performance measures. Also, if managers could be efficient compared to the market; and whether efficiency has occurred because of the manager's skill or pure luck. With the incorporation of the efficiency frontier analysis to the studies and research on the profitability of investment funds, the possibilities of forecasting and planning the portfolio management have been significantly amplified with the support of sturdier methods of multidimensional analysis, such as the Data Envelopment Analysis (DEA) and the Stochastic Frontier Analysis (SFA).

Ceretta and Costa (2001) investigated the performance of stock investment funds by Data Envelopment Analysis, sampling 106 funds in the free portfolio mode from December 1997 to November 1999. They identified seven dominant funds, which were confronted with seven least efficient funds, highlighting the differences in attributes and considerations among them.

Santos, Silveira, Costa, and Da Silva (2005) evaluated the performance of 307 Brazilian mutual stock funds using the stochastic frontiers. The researchers listed the top ten actively managed funds and the last ten in the period from April 2001 to July 2003. They found out that the efficiency of a fund increases along with larger administrative skills to win the market. They also found that portfolios with low volatility tend to be more efficient; and that there was no relationship between the size of the fund and its performance, although this may have been clouded by a survival bias.
De Resende Baima and Costa (2006) checked if the investment expenses and the size of pension funds are directly or inversely related with their performance in the period of 1998-2002. Such authors learned that expenses and the size of pension funds' portfolios are inversely related to the investments' performance. Such findings support the idea that active management is not a good strategy.

Berggrun, Mongrut, Umaña, and Varga (2014) investigated the performance persistence of stock funds in the Brazilian market between 2000 and 2012. They found the evidence that performance endures once there is significant adjusted risk of bid-ask spread between portfolios of better and worse performance. Besides, it can be noticed that such spread happens mostly due to a lower performance of funds in the lower decile, underlining that some fund managers do not have enough skills to win back the investment costs.

Fonseca, Kanitz, and Bassani (2014) checked in their study the performance of 46 Brazilian funds of private equity and venture capital from 1990 to 2013, in comparison to the American market. The internal rate of return (IRR) of Brazilian funds is higher than the average of American funds in the period. Between 1990 and 1997, the funds had lower average performance than private equity funds in the USA, while between 1998 and 2008, the Brazilian funds outperformed the American funds. Therefore, it reflects a learning curve in the Brazilian industry of private equity, and that Brazil is more cyclical than the USA.

Galan, Ramos, and Veiga (2015) estimated the efficiency of a mutual funds sample invested in the United States through stochastic production function. They found that the underlying technology had economies of scale both at the bottom and at the top level of the company, and that informational asymmetry had a significant influence on the efficiency.

In addition, they also found that domestic funds were more efficient than foreign funds, which invested in the US; that funds directly sold to investors were more efficient than the ones sold to financial intermediaries; and the level of inefficiency's persistence was globally high. While in ethical and corporate-oriented funds, the ineffi- 
ciency's persistence was higher, whereas in funds for growth companies, it was lower.

Rebeschini and Leal (2016) tested the version of arbitrage pricing theory (APT) with Brazilian funds of stock investment between 2002 and 2012 by using four macroeconomic factors and a single market factor. The only ones to present the consistent signal of coefficients and high significance frequencies in all periods and fund categories were market risk and the structure of interest rate.

Mamatzkis and $\mathrm{Xu}$ (2016) examined the performance of Chinese mutual funds and the impact of managerial attributes on fund performance over the period from 2005 to 2013, using SFA and other traditional fund performance methods such as Jensen alpha and Sharpe Index. The study revealed that team management in a large fund had a negative impact on its performance; funds managed by long-term managers performed poorer than relatively new fund managers, and that only managers with a Master's Degree had a positive impact on the fund performance.

Maestri and Malaquias (2018) analyzed 6,002 multimarket funds from September 2009 to December 2015 and they concluded that portfolio composition is the factor, which explains best a significant change in the funds' performance. Yet, the best returns adjusted to risk were delivered by less experienced managers, funds, which invested more in fixed income, managers with greater quantity of funds, and larger funds.

In this brief context of empirical experiments discussed so far, it becomes clear that the recent use of DEA and SFA methods has risen the efficiency frontier analysis of investment funds.

\section{AIMS AND METHODS}

The goal of this work is to apply the SFA method on panel data of Investment Funds in Credit Rights (FIDC) of the Brazilian ANBIMA Agro, Commerce, and Industry categories, active from 2012 to 2015. The goal is also to evaluate its relative efficiency and persistence in those years, including Sharpe Index to identify the most and the least recommendable by these two different approaches.

\subsection{The Stochastic Frontier Analysis (SFA) model applied to panel data}

The theoretical basis of the SFA model originates from Aigner, Lovell, and Schmidt (1977) and their proposition of a stochastic frontier production function, considering the additional error of the variable, $V_{i}$ added to the non-negative random variable, $U_{i}$ :

$$
\ln \left(y_{i}\right)=X_{i} \beta+V_{i}-U_{i}, i=1,2, \ldots, n .
$$

The random variable $V_{i}$ accounts for errors and other random factors, such as weather effects, crisis, strikes, etc. in the value of the production variable, along with combined effects of not specified input variables in the production function. The term $V$ is independent and identically distributed; it has a normal distribution with zero mean and constant variance.

The model defined in (1) is called production function of stochastic frontier because the product's values are bounded by the stochastic random variable, $\exp \left(X_{i} \beta+V_{i}\right)$. The random component $V_{i}$ can be positive or negative and thus the stochastic production frontier varies over the deterministic part of the frontier, $\exp \left(X_{i} \beta\right)$.

When this model was incepted in 1977 , it was regarded as the calculation of average technical efficiency for all the observations, except its estimate for each Decision Making Unit (DMU). The solution to the decomposition problem came five years later with Jondrow, Lovell, Materov, and Schmidt (1982).

Six years later, Battese and Coelli (1988) elaborated a generalization of those results for panel data $U_{i}$ and semi-normal distribution. They took the function of frontier production as a basis:

$$
\ln y_{i t}=\ln f p f\left(X_{i t}, \beta\right)+\varepsilon_{i} \text {, }
$$

where $i=1, \ldots, n$ and $t=1, \ldots, T$ index of the DMUs and the time, respectively, $y_{i t}$ is the production volume of the $i$-th DMU at time $t, X_{i t}$ is a matrix of the inputs associated with $i$-th DMU at time $t, \beta$ is the vector of parameters to be estimated, $\varepsilon_{i t}=V_{i t}+U_{i}, U_{i} \leq 0$ has the components defined as (1). 
Thus, for Battese and Coelli (1988), the technical efficiency of a given DMU is defined as the ratio between its average production (in original units) at a given efficiency level and the corresponding average production being $U_{i}$ zero, that is:

$$
E T_{i}=\frac{E\left(y_{i t} \mid U_{i}, X_{i t}\right)}{E\left(y_{i t} \mid U_{i}=0, X_{i t}\right)} .
$$

In the case where the frontier production function is defined by the logarithm of production, the production of $i$-th DMU at time $t$ is $\exp \left(y_{i t}\right)$, and its corresponding measure of technical efficiency is

$$
E T_{i}=\exp \left(U_{i}\right)
$$

This measure is equivalent to the ratio between the production of $i$-th DMU in a given period $t$ :

$$
\exp \left(y_{i t}\right)=\exp \left(X_{i t} \beta+V_{i t}+U_{i}\right)
$$

and the corresponding volume of production, where $U_{i}$ is equal to zero, that is,

$$
\exp \left(X_{i t} \beta+V_{i t}\right)
$$

Putting aside the two-stage models used so far, Kumbhakar, Ghosh, and McGuckin (1991), Reifschneider and Stevenson (1991), and Huang and Liu (1992) proposed the models in which frontier parameters and those of the inefficiency equation are estimated simultaneously. Such formulations presume the existence of associated distribution to the cross-sectional data of sample firms.

Battese and Coelli (1995) extended the Huang and Liu's model (1992) to a panel data and created a specification, where efficiency is expressed as a function of specific variables, including "time trend" and random term. Since this model assigns a structure to the technical efficiency, it is possible to analyze the simultaneous variation of production frontier and efficiency by discriminating the trends associated with frontier dislocations from those related to the dissemination (or not) of best practice. This specification has the advantage of softening the hypothesis of technical efficiency levels and technological frontier invariant over time. Thus,

$$
y_{i t}=\beta_{0}+X_{i} \beta+V_{i}-U_{t}
$$

and

$$
y_{i t}=\beta_{0 i t}+X_{i t} \beta+V_{i t}, \beta_{0 i t}=\beta_{0}-U_{i t},
$$

where $y_{i t}$ denotes the production/service of DMU $i$ at time $t, X_{i t}$ is an input vector associated with the units under analysis in each observation period, $\beta$ are the parameters to be estimated ( $\beta_{0}$ is the intercept of the production frontier), $V_{i t}$ are the stochastic shocks assumed as iid in a normal distribution $N\left(0, \sigma_{v}^{2}\right)$ and distributed independently of the $U_{i t}, U_{i t}$ are non-negative random variables associated to the production inefficiency, and they have, by assumption, a normal distribution shortened with mean $Z_{i t} \delta$ and variance $\sigma^{2}, Z_{i t}$ is a vector of explanatory variables associated with technical inefficiency of the firms involved in the production process, and $\delta$ is a vector of unknown coefficients to be estimated.

The technical efficiency $U_{i t}$ is, by hypothesis, a function of "explanatory" $Z_{i t}$ variables and a vector of unknown coefficients, $\delta$. It is expected that this set of variables be associated with the deviations of production observed in relation to stochastic frontier, $\exp \left(X_{i t} \beta+V_{i t}\right)$. The individual effects related to $U_{i t}$, can be specified as

$$
U_{i t}=Z_{i t} \delta+W_{i t},
$$

where the random variable $W_{i t}$ is defined by the truncation of a normal distribution with zero mean and variance $\sigma^{2}$, provided that the truncation point is in $-Z_{i t} \delta$, i.e., $W_{i t} \geq-Z_{i t} \delta$. This hypothesis is consistent with the fact that $U_{i t}$ has a non-negative truncated distribution $N\left(Z_{i t} \delta, \sigma^{2}\right)$.

The basic assumption of this model is that $U_{i t}$ and $V_{i t}$ are independently distributed throughout $t=1,2, \ldots, T$ and $i=1,2, \ldots, n$. The efficiency of firm $i$ at time $t$ of observation is defined by

$$
T E_{i t}=\exp \left(-U_{i t}\right)=\exp \left(-Z_{i t} \delta-W_{i t}\right) .
$$

And it is based on a mean conditioned to the hypotheses given. It is important to observe that $Z_{i t} \delta+W_{i t}>Z_{i^{\prime} t} \delta+W_{i^{\prime} t^{\prime}}$, for $i \neq i^{\prime}$, does not necessarily imply that $Z_{i t^{\prime}} \delta+W_{i t^{\prime}}>Z_{i^{\prime} t^{\prime}} \delta+W_{i t^{\prime}}$, for $t^{\prime} \neq t$. 
Consequently, the same ordering of DMUs in terms of technical efficiency of production is not applied to all the periods.

\subsection{Specification of the econometric model}

The empirical version of the stochastic frontier analysis model, applied to panel data (Equations 7 to 10 , section 2 ), is

$$
\begin{aligned}
& \ln \text { RENTA }_{i t}=\beta_{0}+\beta_{1} \ln \text { RISCA }_{i t}+ \\
& +\beta_{2} \ln P A T L A_{i t}+\beta_{3} \ln T A D A_{i t}+V_{i t}-U_{i t}
\end{aligned}
$$

and

$$
\begin{aligned}
& U_{i t}=\delta_{0}+\delta_{1} \text { TEMPO }_{i t}+ \\
& +\delta_{2} \text { RENTS }_{i t}+\delta_{3} \text { RISCS }_{i t},
\end{aligned}
$$

where $R E N T A_{i t}$ denotes the profitability of fund $i$ in year $t$, expressed as a percentage, where $i=1$ to 33 and $t=1$ (2012) to 4 (2015) - these indexes are also valid for the other variables of the model, $\beta_{0}$ is the constant coefficient (intercept of the profitability frontier) and $\beta_{1}, \beta_{2}$, and $\beta_{3}$ are the coefficients of the explanatory variables $R I S C A_{i t}$ (annual risk - in units of monthly standard deviation of yields), $P A T L A_{i t}$ (annual equity - in R\$ 1,00 ) and $T A D A_{i t}$ (annual management fee - in percentage), respectively, $V_{i t}$ are stochastic shocks, $U_{i t}$ are non-negative random variables associated to inefficiency of profitability, which have, by assumption, truncated normal distribution with mean $Z_{i t} \delta$ and variance $\sigma^{2}, Z_{i t}$ is a vector of explanatory variables (Equation 12) associated with the funds technical innefficiency, defined by

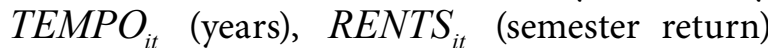
and $\operatorname{RISCS}_{\text {it }}$ (semester risk) in the present case, and $\delta_{0}$ is the constant coefficient and $\delta_{1}, \delta_{2}$, and $\delta_{3}$ are the coefficients of time, semiannual profitability and semiannual risk, respectively.

The explanatory variables included in the profitability function (Equation 11) were defined as being the most common in the studies and in the research on investment funds profitability found in the specialized literature. By exposing the explanatory variables on the inefficiency function (Equation 12), we intend to verify the meanings and the impact of their influence on efficiency, as well as the calculated time trend and the semiannual risk and return - the defi- nition of these last two variables walks side by side with the understanding of Ceretta and Costa Jr (2001).

The FRONTIER Version 4.1 software, available at the Center for Efficiency and Productivity Analysis (CEPA) (2018), was used to quantify the efficiency on stochastic frontier panel of Brazilian FIDC Agro, Commerce, and Industry categories. It follows the parameters of Battese and Corra (1977), where $\sigma_{V}^{2}$ and $\sigma_{U}^{2}$ are replaced by $\sigma^{2}=\sigma_{V}^{2}+\sigma_{U}^{2}$ and $\gamma=\sigma_{U}^{2} / \sigma^{2}$, respectively, which indicates the influence of the one-sided component on global variance and represents the relative importance of the term inefficiency in the panel adjustment. Under these conditions, $\gamma$ must be between 0 and 1 , at the iteration's initialization of the maximization algorithm.

This estimation process makes it possible to include two vectors of explanatory variables. The first one influences the level of frontier profitability (Equation 11), while the second one influences the technical inefficiency (Equation 12). Such characteristics are found in the stochastic frontier efficiency model with panel data, designed by Battese and Coelli (1995).

The data used were extracted from the information system of the Brazilian Association of Financial and Capital Market Entities (ANBIMA) through formal request.

For the composition of the surveyed funds, all investment funds of FIDC Agro, Commerce, and Industry categories of ANBIMA were taken into account, totaling 223 existing funds in the period from 2011 to 2015. Among those, we selected the active ones from 2012 to 2015, neglecting the year of 2011, once it would have reduced the quota of funds to be analyzed.

\section{RESULTS AND DISCUSSION}

Table 1 presents the results regarding the descriptive analysis of the investment funds analyzed. It is noteworthy that the funds obtained positive average returns in three of the four years analyzed. It also stands out that the higher the profitability, the greater the risk involved. 
Table 1. Descriptive analysis

Source: Elaborated by the authors from the research data.

\begin{tabular}{|c|c|c|c|c|c|c|c|c|c|c|c|c|}
\hline \multirow{2}{*}{ Code } & \multirow{2}{*}{ Institution } & \multirow{2}{*}{$\begin{array}{c}\text { Annual } \\
\text { management } \\
\text { fee }\end{array}$} & \multicolumn{2}{|c|}{2012} & \multicolumn{2}{|c|}{2013} & \multicolumn{2}{|c|}{2014} & \multicolumn{2}{|c|}{2015} & \multirow{2}{*}{ Average } & \multirow{2}{*}{$\begin{array}{l}\text { Standard } \\
\text { deviation }\end{array}$} \\
\hline & & & Profitability & Risk & Profitability & Risk & Profitability & Risk & Profitability & Risk & & \\
\hline 130702 & BEM & $0.27 \%$ & $8.59 \%$ & $0.11 \%$ & $8.22 \%$ & $0.10 \%$ & $11.03 \%$ & $0.07 \%$ & $13.51 \%$ & $0.11 \%$ & $10.34 \%$ & $2.46 \%$ \\
\hline 130710 & $B E M$ & $0.27 \%$ & $8.45 \%$ & $0.47 \%$ & $2.95 \%$ & $16.05 \%$ & $8.03 \%$ & $0.32 \%$ & $11.97 \%$ & $0.36 \%$ & $7.85 \%$ & $3.71 \%$ \\
\hline 156876 & CITIBANK & $0.02 \%$ & $7.98 \%$ & $0.10 \%$ & $7.90 \%$ & $0.14 \%$ & $11.38 \%$ & $0.07 \%$ & $13.93 \%$ & $0.11 \%$ & $10.30 \%$ & $2.92 \%$ \\
\hline 156884 & CITIBANK & $0.02 \%$ & $11.76 \%$ & $0.36 \%$ & $23.51 \%$ & $1.41 \%$ & $46.08 \%$ & $0.53 \%$ & $38.78 \%$ & $0.51 \%$ & $30.03 \%$ & $15.39 \%$ \\
\hline 166391 & CONCORDIA & $0.15 \%$ & $9.91 \%$ & $0.13 \%$ & $9.49 \%$ & $0.12 \%$ & $12.41 \%$ & $0.06 \%$ & $1.64 \%$ & $3.37 \%$ & $8.36 \%$ & $4.66 \%$ \\
\hline 166405 & CONCORDIA & $0.15 \%$ & $8.38 \%$ & $0.39 \%$ & $9.92 \%$ & $0.52 \%$ & $-2.09 \%$ & $5.03 \%$ & $-5.48 \%$ & $3.41 \%$ & $2.68 \%$ & $7.62 \%$ \\
\hline 180580 & CONCORDIA & $1.35 \%$ & $5.99 \%$ & $1.45 \%$ & $14.51 \%$ & $3.32 \%$ & $4.03 \%$ & $118.41 \%$ & $3.68 \%$ & $0.12 \%$ & $7.05 \%$ & $5.08 \%$ \\
\hline 187501 & $\mathrm{BEM}$ & $0.10 \%$ & $0.59 \%$ & $2.24 \%$ & $1.01 \%$ & $1.86 \%$ & $5.40 \%$ & $1.29 \%$ & $12.77 \%$ & $0.10 \%$ & $4.94 \%$ & $5.65 \%$ \\
\hline 187518 & BEM & $0.10 \%$ & $-16.15 \%$ & $0.27 \%$ & $-21.82 \%$ & $0.21 \%$ & $-28.75 \%$ & $0.45 \%$ & $-44.73 \%$ & $1.07 \%$ & $-27.86 \%$ & $12.37 \%$ \\
\hline 199461 & OLIVEIRA TRUST DTVM & $0.50 \%$ & $-45.26 \%$ & $49.08 \%$ & $-8.91 \%$ & $33.63 \%$ & $561.74 \%$ & $99.81 \%$ & $14.49 \%$ & $13.63 \%$ & $130.51 \%$ & $288.53 \%$ \\
\hline 199761 & BB DTVM S.A & $0.01 \%$ & $8.41 \%$ & $0.11 \%$ & $8.05 \%$ & $0.10 \%$ & $10.81 \%$ & $0.06 \%$ & $13.23 \%$ & $0.10 \%$ & $10.13 \%$ & $2.40 \%$ \\
\hline 199877 & BB DTVM S.A & $0.01 \%$ & $56.16 \%$ & $5.16 \%$ & $-35.81 \%$ & $4.27 \%$ & $-78.75 \%$ & $4.75 \%$ & $-93.12 \%$ & $14.99 \%$ & $-37.88 \%$ & $67.26 \%$ \\
\hline 223514 & CAIXA & $0.20 \%$ & $-0.36 \%$ & $0.09 \%$ & $0.24 \%$ & $0.09 \%$ & $0.17 \%$ & $0.08 \%$ & $0.19 \%$ & $0.10 \%$ & $0.06 \%$ & $0.28 \%$ \\
\hline 223522 & CAIXA & $0.20 \%$ & $-11.85 \%$ & $8.75 \%$ & $-8.49 \%$ & $5.17 \%$ & $4.95 \%$ & $2.96 \%$ & $21.61 \%$ & $0.93 \%$ & $1.56 \%$ & $15.21 \%$ \\
\hline 226467 & CAIXA & $0.20 \%$ & $-22.27 \%$ & $0.17 \%$ & $-33.33 \%$ & $0.85 \%$ & $-47.46 \%$ & $1.71 \%$ & $-35.24 \%$ & $0.45 \%$ & $-34.58 \%$ & $10.32 \%$ \\
\hline 226475 & CAIXA & $0.20 \%$ & $13.92 \%$ & $0.25 \%$ & $14.62 \%$ & $0.32 \%$ & $-72.71 \%$ & $22.85 \%$ & $11.89 \%$ & $0.96 \%$ & $-8.07 \%$ & $43.11 \%$ \\
\hline 226904 & CITIBANK & $0.73 \%$ & $13.45 \%$ & $0.12 \%$ & $13.01 \%$ & $0.12 \%$ & $15.86 \%$ & $0.12 \%$ & $19.20 \%$ & $0.51 \%$ & $15.38 \%$ & $2.84 \%$ \\
\hline 237728 & OLIVEIRA TRUST DTVM & $0.10 \%$ & $10.38 \%$ & $0.14 \%$ & $0.92 \%$ & $2.26 \%$ & $0.70 \%$ & $3.10 \%$ & $0.97 \%$ & $3.69 \%$ & $3.24 \%$ & $4.76 \%$ \\
\hline 237841 & SOCOPA & $1.50 \%$ & $12.90 \%$ & $0.19 \%$ & $13.21 \%$ & $0.21 \%$ & $14.25 \%$ & $0.27 \%$ & $18.28 \%$ & $0.33 \%$ & $14.66 \%$ & $2.48 \%$ \\
\hline 237868 & SOCOPA & $1.50 \%$ & $35.73 \%$ & $2.85 \%$ & $-35.55 \%$ & $4.29 \%$ & $-8.02 \%$ & $5.54 \%$ & $-7.43 \%$ & $3.29 \%$ & $-3.81 \%$ & $29.45 \%$ \\
\hline 237914 & BEM & $0.24 \%$ & $6.00 \%$ & $0.03 \%$ & $5.92 \%$ & $0.10 \%$ & $5.87 \%$ & $0.11 \%$ & $7.58 \%$ & $0.60 \%$ & $6.34 \%$ & $0.83 \%$ \\
\hline 237922 & OLIVEIRA TRUST DTVM & $0.10 \%$ & $1.57 \%$ & $2.19 \%$ & $4.82 \%$ & $3.70 \%$ & $7.80 \%$ & $1.59 \%$ & $14.30 \%$ & $1.24 \%$ & $7.12 \%$ & $5.42 \%$ \\
\hline 239631 & BNY MELLON & $0.60 \%$ & $27.69 \%$ & $0.39 \%$ & $16.75 \%$ & $0.30 \%$ & $15.46 \%$ & $0.53 \%$ & $15.32 \%$ & $0.18 \%$ & $18.81 \%$ & $5.96 \%$ \\
\hline 240567 & PLANNER & $1.35 \%$ & $10.62 \%$ & $0.14 \%$ & $-59.24 \%$ & $18.31 \%$ & $-54.72 \%$ & $10.31 \%$ & $-4.15 \%$ & $1.33 \%$ & $-26.87 \%$ & $35.33 \%$ \\
\hline 242691 & CONCORDIA & $1.50 \%$ & $-2.15 \%$ & $2.09 \%$ & $-3.02 \%$ & $0.52 \%$ & $-0.47 \%$ & $0.27 \%$ & $2.84 \%$ & $0.33 \%$ & $-0.70 \%$ & $2.59 \%$ \\
\hline 244351 & OLIVEIRA TRUST DTVM & $0.10 \%$ & $10.46 \%$ & $0.15 \%$ & $0.92 \%$ & $2.26 \%$ & $0.70 \%$ & $3.10 \%$ & $0.97 \%$ & $3.69 \%$ & $3.26 \%$ & $4.80 \%$ \\
\hline 252484 & BNY MELLON & $1.50 \%$ & $-68.21 \%$ & $18.23 \%$ & $-2.86 \%$ & $0.93 \%$ & $-50.51 \%$ & $14.18 \%$ & $-0.34 \%$ & $1.04 \%$ & $-30.48 \%$ & $34.14 \%$ \\
\hline 253979 & CITIBANK & $0.42 \%$ & $-51.27 \%$ & $5.20 \%$ & $-98.88 \%$ & $30.49 \%$ & $999.77 \%$ & $372.46 \%$ & $-15.68 \%$ & $1.51 \%$ & $208.49 \%$ & $528.62 \%$ \\
\hline 255610 & SOCOPA & $0.65 \%$ & $-5.44 \%$ & $5.44 \%$ & $19.05 \%$ & $4.24 \%$ & $24.29 \%$ & $8.41 \%$ & $-70.12 \%$ & $19.88 \%$ & $-8.06 \%$ & $43.36 \%$ \\
\hline 257508 & SOCOPA & $1.50 \%$ & $11.07 \%$ & $0.14 \%$ & $10.59 \%$ & $0.13 \%$ & $14.80 \%$ & $0.09 \%$ & $18.15 \%$ & $0.14 \%$ & $13.65 \%$ & $3.54 \%$ \\
\hline 257516 & SOCOPA & $1.50 \%$ & $24.96 \%$ & $3.36 \%$ & $-8.01 \%$ & $2.20 \%$ & $5.63 \%$ & $2.87 \%$ & $17.29 \%$ & $1.54 \%$ & $9.97 \%$ & $14.38 \%$ \\
\hline 259721 & GRADUAL CCTVM S A & $0.50 \%$ & $21.65 \%$ & $2.97 \%$ & $24.74 \%$ & $4.34 \%$ & $28.77 \%$ & $2.35 \%$ & $4.79 \%$ & $3.31 \%$ & $19.99 \%$ & $10.55 \%$ \\
\hline 261114 & CITIBANK & $0.22 \%$ & $-52.33 \%$ & $4.66 \%$ & $-90.03 \%$ & $189.60 \%$ & $77.33 \%$ & $123.31 \%$ & $-32.66 \%$ & $23.22 \%$ & $-24.42 \%$ & $71.89 \%$ \\
\hline \multicolumn{2}{|c|}{ Total average } & - & $1.56 \%$ & $3.56 \%$ & $-5.93 \%$ & $10.06 \%$ & $46.78 \%$ & $24.46 \%$ & $-0.96 \%$ & $3.22 \%$ & $10.36 \%$ & $39.03 \%$ \\
\hline
\end{tabular}


Table 2. Result of the stochastic frontier panel estimation on funds efficiency, defined by Equations (11) and (12)

Source: Elaborated by the authors from the research data.

\begin{tabular}{|c|c|c|c|}
\hline \multicolumn{4}{|c|}{ Output from the program FRONTIER (Version 4.1c) } \\
\hline \multicolumn{4}{|c|}{ The final mle estimates are: } \\
\hline Betas & Coefficient & Standard-error & $t$-ratio \\
\hline beta 0 & $-0.41400798^{a}$ & 0.42655068 & -0.97059505 \\
\hline beta 1 & $0.10051880^{b}$ & 0.026649946 & 3.7718200 \\
\hline beta 2 & $0.049520706^{c}$ & 0.025521711 & 1.9403364 \\
\hline beta 3 & $0.032779726^{d}$ & 0.035459617 & 0.92442415 \\
\hline delta 0 & $2.3770585^{e}$ & 0.41433322 & 5.7370696 \\
\hline delta 1 & $0.044862099^{f}$ & 0.11499648 & 0.39011714 \\
\hline delta 2 & $-2.89811691^{\mathrm{g}}$ & 0.37259384 & -7.7782200 \\
\hline delta 3 & $0.012735348^{h}$ & 0.0040930813 & 3.1114331 \\
\hline Sigma-squared & $0.50599990^{i}$ & 0.14132345 & 3.5804384 \\
\hline Gamma & $0.84609570^{j}$ & 0.050952629 & 66.05536 \\
\hline
\end{tabular}

Log likelihood function $=-64.716585$

LR test of one-sided error $=116.69662$

Note: "a" statistically significant at 0.20 , "b" statistically significant at 0.0005 , "c" statistically significant at 0.05 , "d" statistically significant at 0.20 , "e" statistically significant at 0.0005 ; " $f$ " not statistically significant, " $g$ " statistically significant at 0.0005 ; " $h$ " statistically significant at 0.0025 , “i" statistically significant at 0.00055 ; and "j" statistically significant at 0.0005 .

The main results obtained from the estimation of Equations 11 (Profitability) and 12 (Inefficiency), which constitute the stochastic frontier panel of efficiency of the funds analyzed, were processed in FRONTIER 4.1 (CEPA, 2018) and are displayed in Table 2.

Table 2 shows that the coefficients are statistically significant at $5 \%$ levels or up, except for "beta 0" and "beta 3", which begin to have significance at 0.20 , and "delta 1 ", which is not statistically significant. The first case does not bring detrimental consequences to the analysis, since it concerns the constant coefficient. As for the inexpressive statistical significance of "beta 3 ", it is due to the small variability of management rates. As for "delta 1", it means that the variations of efficiency during the 4 years were minimum (see Table 2). This aspect is proven by the positive signal on coefficient "delta 1", indicating the exiguous reductions in the inefficiency during all those years.

The application of the stochastic frontier panel with effects on inefficiency is statistically justifiable, as shown in the one-sided likelihood ratio test $(\mathrm{LR}=116.6966)$ and the test on the "gamma $-\gamma$ " $(t$ ratio $=66.0553)$ parameter, both highly significant.

As for the empirical interpretation of coefficients $\beta_{1}, \beta_{2}$, and $\beta_{3}$ in general terms, increments in the Annual Risk, in the Shareholders Equity and in the Annual Management Rate brought increments in the funds' Annual Profitability during the 4 years analyzed here.

The risk/return ratio is a relation conceived and widely accepted in finance, that is, the higher the risk taken by managers, the larger the demand for future returns (conversely, the lower the risk, the smaller the demand for returns). This aspect has been confirmed here by the positive signal and by the increased statistical significance of $\beta_{1}$.

The positive impact on the size of the fund about its profitability - represented by the value of the net worth - corresponds to the results found by Chen, Hong, Huang, and Kubik (2004), Heaney (2007), Milani and Ceretta (2013), Moura and Fonseca (2015), Maestri and Malaquias (2018). It means that the higher the quantity of resources available to managers, the more favorable their strategies and opportunities might be to reach better future performance. This also can be understood as the fund size influence on the investors' choice; or yet, as the tendency towards funds with higher profitability in a given period, which received more financial resources in the next moment.

In turn, the insufficient statistical significance on the coefficient of management rate happens due to 
the invariability of its intra-fund values in 4 years of the study.

As for the estimates obtained for the function of inefficiency (Equation 12), we verified that the coefficient $\delta_{1}$ is not statistically different from zero, indicating that over the years, fund managers are not generally able to decrease the inefficiency rates at significant levels. A proof of it is that an important decrease in the average efficiency, in relation to the previous year occurred only in 2013. In other years, the average rates of efficiency stabilized (Table 3).

Table 3. Stochastic frontier efficiency rates (SFER) of funds between the years 2012-2015 by tercile in descending order

Source: Provided by the authors from the research data.

\begin{tabular}{|c|c|c|c|c|c|c|c|}
\hline \multicolumn{2}{|c|}{2012} & \multicolumn{2}{|c|}{2013} & \multicolumn{2}{|c|}{2014} & \multicolumn{2}{|c|}{2015} \\
\hline Fund & $\begin{array}{c}\text { SFER } \\
(\%)\end{array}$ & Fund & $\begin{array}{c}\text { SFER } \\
(\%)\end{array}$ & Fund & $\begin{array}{c}\text { SFER } \\
(\%)\end{array}$ & Fund & $\begin{array}{c}\text { SFER } \\
(\%)\end{array}$ \\
\hline \multicolumn{8}{|c|}{ First tercile } \\
\hline "C" & 86.32 & " $X "$ & 82.09 & $\mathrm{~J}$ & 96.41 & $D$ & 85.72 \\
\hline "X" & 84.22 & $\mathrm{P}$ & 81.96 & $\mathrm{DD}$ & 96.13 & "A" & 83.36 \\
\hline $\mathrm{T}$ & 83.87 & "A" & 81.56 & D & 87.21 & $\mathrm{H}$ & 82.98 \\
\hline L & 83.83 & $E$ & 81.02 & "A" & 83.41 & $\mathrm{~N}$ & 82.18 \\
\hline$R$ & 83.43 & D & 80.74 & $\mathrm{E}$ & 83.10 & "X" & 82.11 \\
\hline $\mathrm{P}$ & 82.92 & "FF" & 80.60 & "C" & 82.72 & G & 82.05 \\
\hline $\mathrm{BB}$ & 82.90 & $S$ & 80.27 & "FF" & 82.37 & "FF" & 81.71 \\
\hline Z & 82.74 & "C" & 79.94 & $\mathrm{~S}$ & 79.73 & "C" & 81.34 \\
\hline "A" & 81.51 & $\mathrm{~F}$ & 79.61 & $\mathrm{M}$ & 79.33 & $\mathrm{~S}$ & 80.56 \\
\hline$E$ & 81.32 & M & 79.34 & B & 79.30 & B & 79.88 \\
\hline "FF" & 80.79 & Q & 78.73 & "X" & 79.29 & $\mathrm{P}$ & 79.63 \\
\hline \multicolumn{8}{|c|}{ Third tercile } \\
\hline V & 74.02 & GG & 68.54 & $\mathrm{BB}$ & 69.75 & $\mathrm{HH}$ & 68.08 \\
\hline $\mathrm{H}$ & 70.12 & $\mathrm{~N}$ & 67.43 & "II" & 65.68 & J & 67.73 \\
\hline AA & 66.85 & B & 62.24 & $\mathrm{~F}$ & 62.50 & DD & 65.23 \\
\hline “O” & 65.36 & "I" & 61.36 & $\mathrm{~T}$ & 58.51 & $\mathrm{~F}$ & 63.39 \\
\hline $\mathrm{EE}$ & 64.85 & $\mathrm{~J}$ & 53.83 & "I" & 53.47 & E & 62.98 \\
\hline "I" & 63.89 & "O" & 51.32 & "O" & 37.94 & $\mathrm{~T}$ & 60.86 \\
\hline $\mathrm{N}$ & 55.02 & L & 48.31 & G & 37.25 & "O" & 53.60 \\
\hline $\mathrm{DD}$ & 33.23 & $\mathrm{~T}$ & 44.06 & z & 29.97 & "II" & 40.44 \\
\hline "II" & 31.99 & Z & 30.39 & CC & 27.18 & "I" & 39.64 \\
\hline$J$ & 29.99 & "II" & 4.78 & P & 21.92 & $\mathrm{EE}$ & 18.66 \\
\hline \multirow[t]{2}{*}{$\mathrm{CC}$} & 16.57 & DD & 0.94 & $L$ & 15.05 & $\mathrm{~L}$ & 4.74 \\
\hline & $71.28^{*}$ & & $66.36^{*}$ & & $67.74^{*}$ & & $68.64^{*}$ \\
\hline
\end{tabular}

Notes: * Annual averages.

1) The average efficiency through 4 years was $68.51 \%, 2$ ) in the first and third terciles, the funds in bold and in quotes, are the ones who remained in the same tercile during the 4 years; the ones that are only in bold remained in the same tercile for 3 years. P.S.: the second tercile was omitted.

As for the coefficients $\delta_{2}$ and $\delta_{3}$ of RENTS and RISCS variables, respectively, semiannual profit- ability and risk are highly important statistically (at significance levels superior to $1 \%$ ). It means the increases occurred result in the annual efficiency increase (in case of semiannual profitability, delta 2 is negative), while, on the other hand the increments in semiannual risk (delta 3 is positive) result in the decreases in annual efficiency, contrary to the impact of the annual risk over the annual profitability.

The efficiency rates (Table 3) resulting from the processing in frontier 4.1 were multiplied by 100 to make its interpretation and understanding easier. Its literal interpretation is very simple. For example, the score obtained by fund C, $86.32 \%$, shows that in 2012, the referred fund yielded $86.32 \%$ of the total amount (100\%) it would have yielded if it were operating in the efficiency frontier.

It can be observed in Table 3 that the most efficient and stable funds were A, C, X, and FF. Such funds kept efficiency rates in the first tercile during 4 years analyzed. Funds D, E, P, and S are in an inferior position. They were in this same tercile during 3 out of 4 years considered.

The less efficient funds and persistent in the inefficiency are I, O, and II, which figured in the third tercile during 4 years. Funds J, L, T, and DD were not so bad situated and remained in the same tercile for 3 years.

For the sake of comparison, these stochastic frontier efficiency rates were collated according to one of the most popular funds assessment measures, the Sharpe Index (Table 4).

This table indicates that funds with better performance and greater stability, that is, those which retained the performance ratios in the first tercile were A, C, M, K, and FF. Funds E, Q, S, U are in an inferior position. They remained in the same tercile in 3 out of 4 years considered.

Funds EE, J, L, and II are persistently bad performers, figuring in the third tercile in 4 years. Funds $\mathrm{HH}, \mathrm{DD}$, and $\mathrm{T}$ were in a less critical situation. They remained in the same tercile for 3 years.

From these results, we may infer that the best and safer funds to invest are A, C and FF, which figured in the first tercile during the time observed, 
Table 4. Sharpe Indexes (SI) of the funds in the years 2012-2015 by tercile in descending order

Source: Provided by the authors from the research data.

\begin{tabular}{|c|c|c|c|c|c|c|c|}
\hline \multicolumn{2}{|c|}{2012} & \multicolumn{2}{|c|}{2013} & \multicolumn{2}{|c|}{2014} & \multicolumn{2}{|c|}{2015} \\
\hline Fund & SI & Fund & SI & Fund & SI & Fund & SI \\
\hline \multicolumn{8}{|c|}{ First tercile } \\
\hline U & 31.2633 & "M" & 11.6423 & $E$ & 18.6324 & $\mathrm{H}$ & 11.2022 \\
\hline "M" & 11.6696 & "K" & 10.9935 & "K" & 17.3290 & "K" & 10.7850 \\
\hline "C" & 10.3148 & "A" & 10.7938 & "A" & 17.0213 & "A" & 10.5975 \\
\hline "K" & 9.8266 & U & 10.7912 & "C" & 16.5830 & "C" & 10.3317 \\
\hline "A" & 9.6489 & Q & 9.7856 & "FF" & 12.7960 & "M" & 9.8805 \\
\hline Q & 9.2138 & $E$ & 9.5110 & "M" & 12.6559 & G & 8.7149 \\
\hline$E$ & 8.5060 & "FF" & 8.6426 & Q & 9.8488 & "FF" & 8.6857 \\
\hline z & 8.0090 & "C" & 7.6983 & U & 9.6812 & $x$ & 6.4477 \\
\hline "FF" & 7.7290 & $S$ & 5.4458 & $S$ & 4.2870 & $S$ & 3.6322 \\
\hline $\mathrm{R}$ & 7.7212 & $x$ & 3.9353 & AA & 3.6307 & $\mathrm{AA}$ & 3.1401 \\
\hline BB & 7.6019 & I & 3.7920 & B & 3.3866 & B & 3.1078 \\
\hline \multicolumn{8}{|c|}{ Third tercile } \\
\hline V & 0.4640 & $\mathrm{HH}$ & 0.2875 & $\mathrm{~F}$ & 0.1948 & 1 & 0.5166 \\
\hline $\mathrm{H}$ & 0.4484 & V & 0.2837 & $\mathrm{~T}$ & 0.1660 & $\mathrm{HH}$ & 0.3165 \\
\hline $\mathrm{HH}$ & 0.4092 & "EE" & 0.2807 & "EE" & 0.1477 & $E$ & 0.3015 \\
\hline GG & 0.3718 & $N$ & 0.1772 & "J" & 0.0663 & $T$ & 0.2813 \\
\hline "L" & 0.3024 & "L" & 0.1504 & "L" & 0.0447 & $\mathrm{~F}$ & 0.2769 \\
\hline "EE" & 0.1737 & $\mathrm{~T}$ & 0.1502 & Z & 0.0439 & $R$ & 0.2738 \\
\hline "II" & 0.1024 & B & 0.0641 & $\mathrm{CC}$ & 0.0349 & BB & 0.2738 \\
\hline $\mathrm{N}$ & 0.1007 & "J" & 0.0271 & $\mathrm{DD}$ & 0.0295 & "Ј" & 0.0840 \\
\hline $\mathrm{DD}$ & 0.0938 & Z & 0.0223 & "II" & 0.0144 & "II" & 0.0290 \\
\hline $\mathrm{CC}$ & 0.0174 & "II" & 0.0005 & $\mathrm{P}$ & 0.0119 & "EE" & 0.0150 \\
\hline “J" & 0.0112 & DD & 0.0004 & G & 0.0088 & "L" & 0.0046 \\
\hline
\end{tabular}

Notes: 1) In the Sharpe Index calculation, volatility was not deducted, 2) in the first and third terciles, the funds in bold and in quotes remained in the same tercile during 4 years; the ones that are only in bold remained in the same tercile for 3 years. P.S.: the second tercile was omitted.

both by SFER and SI. Similarly, in the second place for 3 years are funds $E$ and $S$.

Regarding the third tercile, only fund II is positioned in 4 years by the two indicators. Similarly, in the second place for 3 years are funds T and DD.
In a nutshell, it is recommendable to the investor to prioritize investments in funds $\mathrm{A}, \mathrm{C}$, and $\mathrm{FF}$ in the short-term decision-making in which funds to invest; and, to a lesser extent, to invest in funds $\mathrm{E}$ and S. Not recommended to be invested are funds II, $\mathrm{T}$, and DD.

\section{CONCLUSION}

For the population of the Brazilian FIDC Agro, Commerce, and Industry categories, which remained active from 2012 to 2015, the specification on the stochastic frontiers panel seems adequate to measure and analyze the individual efficiency rates, as well as their annual averages.

The coefficients of management rate and time are not statistically significant at levels higher than 5\%. In the first case, insufficient statistical significance occurred due to the invariability of intra-fund rates over 4 years. In the second case, it means that efficiency variations do not have statistical importance, an aspect, which is numerically visible through inexpressive reductions in annual average inefficiency. In other words, managers were not able to aggregate the significant decreases in the inefficiency rates over the analyzed years. 
In case of semiannual profitability, it is observed that the increases occurred because of increments in the annual efficiency. As for the increases regarding the semiannual risk, they resulted in decreases in annual efficiency, contrary to the impact of annual risk over annual profitability.

In this scenario, considering the stochastic frontier of efficiency indexes and the Sharpe Index, it is recommended for the investor to prioritize the investments in the funds $\mathrm{A}, \mathrm{C}$, and FF, regarding the shortterm decision-making in which funds to invest; and, to a lesser extent, to invest in the funds $\mathrm{E}$ and $\mathrm{S}$. Not recommended to be invested are funds II, T, and DD.

The results obtained here encourage the new studies and research. As for the specification of the analysis model, it is necessary to test other functional forms and variables during a longer timespan for further observation, also, including Data Envelopment Analysis.

The results convey the practical applications to investment fund managers, and so it is to financial institutions that manage the investments. It is important to understand that some variables shall be considered in order to be a better performance of investment funds, for instance, the variables size and risk after investment (either six-monthly or yearly). In such a manner, the fund size can impact positively on the performance of future applications.

With these measures, we hope to achieve a new methodological formulation to be used as an efficient and effective instrument in order to help the investors choose the best and the safest funds to invest.

The current studies can go further towards other categories of Brazilian investment, as well as to emerging and consolidated economies, even if it needs future scientific evidence.

\section{ACKNOWLEDGMENT}

We thank the Universidade Regional Integrada do Alto Uruguai e das Missões - URI Santo Ângelo for the resources available for the translation of the article.

\section{REFERENCES}

1. Aigner, D. J., Lovell, C. A. K., \& Schmidt, P. (1977). Formulation and estimation of stochastic frontier production function models. Journal of Econometrics, 6(1), 2137. https://doi.org/10.1016/03044076(77) $90052-5$

2. Amaral, H. F., Vilaça, C. S. I., Barbosa, C. F. M., \& Bressan, V. G. F. (2004). Fundos de pensão como financiadores da atividade econômica. Revista de Administração de Empresas, 44(2), 79-91. http://dx.doi.org/10.1590/ S0034-75902004000200007

3. ANBIMA (2017). Consolidado Histórico de Fundos de Investimento. Retrieved from http://www.anbima.com.br/pt_br/ informar/estatisticas/fundosde-investimento/fi-consolidado- historico.htm (accessed on May 15, 2018).

4. Baggio, D. K. (2012). Los fondos de inversión socialmente responsable de Brasil. 2012. Tese (Doutorado em Contabilidade e Finanças). Faculdade de Economia e Empresas, Universidad de Zaragoza. Zaragoza.

5. Baggio, D. K., Ferruz, L. A., \& Marco, I. S., (2010). Es el desempeño de los fondos de inversión de Brasil un indicador de movimiento futuro de su patrimonio? El Trimestre Economico, 77(306), 445-471. Retrieved from http://www.scielo. org.mx/scielo.php?script=sci_ arttext\&pid=S2448-718X2010000 200445\&lng=es\&tlng=es
6. Baggio, D. K., Silveira, J. S. T., Schneider, I. N., Maciel, A. C., \& Oliva, E. C. (2018). Las medidas de performance en la gestión de fondos de inversión socialmente responsables. Revista Academica Contribuciones a la Economia. Retrieved from https://eumed.net/ rev/ce/2018/2/gestion-fondosinversion.html

7. Barbosa, A., \& Sarto, J. L. M. (2007). Aplicación de las Medidas Clásicas de Performance en los Fondos de Inversión Brasileños de Renta Variables. Revista Contabilidade e Finanças da USP, 44, 86-104. https://doi.org/10.1590/S151970772007000200008 
8. Battese, G. E., \& Coelli, T. J. (1988). Prediction of FirmLevel Technical Efficiencies with a Generalized Frontier Production Function and Panel Data. Journal of Econometrics, 38, 387-399. https://doi.org/10.1016/03044076(88)90053-X

9. Battese, G. E., \& Coelli, T. J. (1995). A Model for Technical Inefficiency Effect in Stochastic Frontier Production for Panel Data. Empirical Economics, 20, 325-45. https://doi. org/10.1007/BF01205442

10. Battese, G. E., \& Corra, G. S. (1977). Estimation of a Production Frontier Model: With Application to the Pastoral Zone off Eastern Australia. Australian Journal of Agricultural Economics, 21, 169-179. https://doi. org/10.1111/j.1467-8489.1977. tb00204.x

11. Berggrun, L., Mongrut, S., Umaña, B., \& Varga, G. (2014). Persistence in equity fund performance in Brazil. Emerging Markets Finance and Trade, 50(2), 16-33. https:// doi.org/10.2753/REE1540496X500202

12. Carhart, M. M. (1997). On persistence in mutual fund performance. Journal of Finance, 52(1), 57-82. https:/doi. org/10.1111/j.1540-6261.1997. tb03808.x

13. Casaccia, M. C. (2009). Análise do desempenho dos fundos de investimentos em ações brasileiros. Trabalho de conclusão de curso (Administração). Escola de Administração, Universidade Federal do Rio Grande do Sul, Porto Alegre. Retrieved from https://docplayer.com. br/18457374-Analise-do-desempenho-de-fundos-de-investimentos-em-acoes-brasileiros.html

14. CEPA - Center for Efficiency and Productivity Analysis. (2018). Frontier Version 4.1. School of Economics. The University of Queensland, Australia. Retreived from https://economics.uq.edu.au/ cepa/software (accessed on June 6, 2018).

15. Ceretta, P. S., \& Costa Jr, N. C. A. (2001). Avaliação e seleção de fundos de investimento: um enfoque sobre múltiplos atributos. Revista de Administração Contemporânea (RAC), 5, 07-22. https://doi.org/10.1590/S141565552001000100002

16. Chen, J., Hong, H., Huang, M., \& Kubik, J. D. (2004). Does Fund Size Erode Mutual Fund Performance? The Role of Liquidity and Organization. The American Economic Review, 94(5), 1276-1302. https://doi. org/10.1257/0002828043052277

17. De Resende Baima, F., \& da Costa, Jr. N. C. (2006). The Influence of Fund Size and Investment Expenses on the Performance of Pension Funds in Brazil. Latin American Business Review, 6(3), 113-132. https://doi.org/10.1300/ J140v06n03_05

18. Fama, E. F. (1970). Efficient capital markets: a review of theory and empirical work. Journal of Finance, 25(2), 383-417. http://dx.doi. org/10.2307/2325486

19. Fama, E. F., \& French, K. R. (1993) Common risk factors in the returns on stocks and bonds. Journal of Financial Economics, 33(1), 3-56. https://doi.org/10.1016/0304405X(93)90023-5

20. Fama, E. F., \& French, K. R. (2010). Luck versus skill in the cross section of mutual funds returns. Journal of Finance, 65(5), 1915-1947. https://doi.org/10.1111/j.15406261.2010.01598.x

21. Fonseca, M. A. M. A., Kanitz, R. V., \& Bassani, R. H. (2014). Private Equity and Venture Capital Industry Performance in Brazil: 1990-2013. The Journal of Private Equity, 17(4), 48-58. Retrieved from https://www.jstor.org/stable/43503820

22. Franz, P. R. G., \& Figueiredo, A. C. (2003). Avaliação da capacidade de market timing dos administradores de fundos mútuos de ações no Brasil. Revista de Economia e Administração, 2(1), 33-46. Retrieved from http:// www.spell.org.br/documentos/ ver/25626/avaliacao-da-capacidade-de-market-timing-dos-administradores-de-fundos-mutuosde-acoes-no-brasil/i/pt-br
23. Fundação Getúlio Vargas (2017). Anuário da Indústria de Fundos de Investimento. São Paulo: FGV. Retrieved from https://cef.fgv. br/sites/cef.fgv.br/files/anuario_ fgv_2017-atual.pdf

24. Galan, J., Ramos, S. B., \& Veiga, H. (2015). An Analysis of the dynamics of efficiency of mutual funds. Business Research Unit/ UNID. Universidad Carlos III de Madrid, Department of Statistics, Spain; Instituto Flores de Lemus. Portugal. Retrieved from https:// pdfs.semanticscholar.org/068b/58 2c30624e1cd78afe7e60874ee7c04 acf78.pdf

25. Grinblatt, M., \& Titman, S. (1989). Mutual fund performance: An analysis of quarterly portfolio holdings. Journal of Business, 63, 393-416. http://dx.doi. org/10.1086/296468

26. Heaney, R. A. (2008). Australian Equity Mutual Fund Size Effects. Accounting \& Finance, 48(5), 807827. Retrieved from http://ssrn. com/abstract $=1291211$

27. Henrikson, R. D. (1984). Market timing and mutual fund performance: an empirical investigation. Journal of Business, 57(1), 73-96. Retrieved from http://www.jstor. org/stable/2352889

28. Henrikson, R. D., \& Merton, R. C. (1981). On market timing and investment performance II: statistical procedures for evaluating forecasting skill. Journal of Business, 54(4), 513-533. Retrieved from http://www.jstor.org/stable/2352722

29. Huang, C. J., \& Liu, J. T. (1992). Stochastic production frontier in the Taiwan electronics industry. Department of Economics Vanderbilt University. Nashville. Retrieved from https://books.google.com. br/books/about/Stochastic_production_frontier_in_the_Ta. html?id=oCyyAAAAIAAJ\&redir $\mathrm{esc}=\mathrm{y}$

30. Jegadeesh, N., \& Titman, S. (1993). Returns to buying winners and selling losers: implications for stock market efficiency. The Journal of Finance, 48(1), 65-91. https:// doi.org/10.1111/j.1540-6261.1993. tb04702.x 
31. Jensen, M. (1968). The performance of mutual funds in the period 1945-1964. Journal of Finance, 23(2), 389-416. https:// doi.org/10.1111/j.1540-6261.1968. tb00815.x

32. Jondrow, J., Lovell, C. A. K., Materov, I. S., \& Schmidt, P. (1982). On the estimation of technical efficiency in the stochastic frontier production function model. Journal of Econometrics, 19(2-3), 233238. https://doi.org/10.1016/03044076(82)90004-5

33. Kumbhakar, S. C., Ghosh, S., \& McGuckin, J. T. (1991). A generalized production frontier approach for estimating of inefficiency in U.S. dairy farms. Journal of Business and Economics Statistics, 9(3), 279-286. Retrieved from https:// www.jstor.org/stable/1391292

34. Leusin, L. M. C., \& Brito, R. D. (2008). Market timing e avaliação de desempenho dos fundos brasileiros. Revista de Administração de Empresas, 48(2), 22-36. http://dx.doi.org/10.1590/ S0034-75902008000200003

35. Maestri, C. O. N. M., \& Malaquias, R. F. (2018). Aspects of manager, portfolio allocation, and fund performance in Brazil. Revista Contabilidade \& Finanças, 29(76), 82-96. http://dx.doi. org/10.1590/1808-057x201804590

36. Malacrida, M. J., Yamamoto, M., Lima, G. A., \& Pimentel, R. (2007). Gestão ativa dos fundos de investimentos: uma análise de desempenho. Retrieved from http://www.congressousp.fipecafi.org/artigos72007/430.pdf (accessed on June 9, 2018).

37. Mamatzkis, E., \& Xu, B. (2016). Managerial attributes and Equity mutual fund performance: evidence from China. Munich Personal RePEc Archive, 76139. Retrieved from https://mpra. ub.uni-muenchen.de/76139/

38. Markowitz, H. M. (1952). Portfolio selection. The Journal of Finance, 7(1). http://dx.doi. org/10.1111/j.1540-6261.1952. tb01525.x

39. Matos, P., \& Nave, A. (2012). Fundos de investimento em ações no Brasil: performance e expertise de gestão. Brazilian Business Review, 01-38. Retrieved from http:// www.spell.org.br/documentos/ ver/9111/fundos-de-investimentoem-acoes-no-brasil--performancee-expertise-de-gestao/i/pt-br

40. Mayorga, J. A., \& Marcos, Y. B. (1996). Rentabilidad y costes de los fondos de inversión. Perspectivas del Sistema Financiero, 55, 50-74.

41. Merton, R. C. (1981). On the market timing and investment performance. I. An equilibrium theory of value for market forecasts. Journal of Business, 54(3), 363-406. http://dx.doi.org/10.1086/296137

42. Milani, B., \& Ceretta, P. S. (2013). Efeito tamanho nos fundos de investimento brasileiros. Revista de Administração da UFSM, 6(1), 119-138. Retrieved from https://www.redalyc.org/ pdf/2734/273428927009.pdf

43. Moura, L. B., \& Fonseca, M. A. R. (2015). Avaliação da Relação entre Tamanho e Desempenho de Fundos de Ações: O Caso dos Fundos de Bancos de Varejo. Anais do VI Congresso Nacional de Administração e Contabilidade AdCont 2015.

44. Rebeschini, A. M., \& Leal, R. P. (2016). Stock Fund Returns and Macroeconomic Variables in Brazil. Latin American Business Review, 17(2), 139-161. https:// doi.org/10.1080/10978526.2016. 1171719

45. Reifschneider, D., \& Stevenson, R. (1991). Systematic departures from the frontier: A framework for the analysis of firm inefficiency. International Economic Review, 32(3), 715-723. Retrieved from https://www.jstor.org/ stable/2527115

46. Santos, A. A. P., Silveira, J. S. T., Costa Jr, N. C. A., \& Da Silva, S. (2005). Evaluating Brazilian mutual funds with stochastic frontiers. Economics Bulletin, 13(2), 1-6. Retrieved from http://www. accessecon.com/pubs/EB/2005/ Volume13/EB-05M20002A.pdf

47. Sharpe, W. F. (1964). Capital asset prices: A theory of market equilibrium under conditions of risk. Journal of Finance, 19, 425-442. https://doi. org/10.1111/j.1540-6261.1964. tb02865.x

48. Sharpe, W. F. (1966). Mutual fund performance. Journal of Business, 39, 19-138. Retrieved from http:// www.jstor.org/stable/2351741

49. Silva, W. C. (2012). Sorte vs Habilidade na análise de desempenho de fundos de investimento em ações no Brasil. Dissertação (Mestrado em Economia) - Programa de Pós-Graduação em Economia. Universidade Federal do Ceará, Fortaleza.

50. Treynor, J. L. (1965). How to rate management of investment funds? Harvard Business Review, 43, 63-75. https://doi. org/10.1002/9781119196679.ch10

51. Treynor, J., \& Mazuy, M. (1966). Can mutual funds outguess the market? Harvard Business Review, 44, 131-136. Retrieved from https://users.business.uconn.edu/ jgolec/Treynor-Mazuy.pdf

52. Vargas, M. M. (2006). Fondos de Inversión españoles: Análisis empírico de eficiencia y persistencia en la gestión. Tesis (Doutorado em Contabilidade e Finanças) - Faculdade de Economia e Empresas. Universidad de Zaragoza. Zaragoza. 